\title{
A LOGTREEMM SZEMLÉLTETÉSE
}

\section{DEMONSTRATION OF THE LOGTREEMM}

\author{
Bera Bálint $^{1}$, Pokorádi László ${ }^{2}$ \\ ${ }^{1}$ Óbudai Egyetem Bánki Donát Gépész és Biztonságtechnikai Mérnöki Kar, \\ egyetemi hallgató, Magyarország 1081 Budapest, Népszínház u. 8.; +36 30 \\ 5911456 balintbera@gmail.com \\ ${ }^{2}$ Óbudai Egyetem Bánki Donát Gépész és Biztonságtechnikai Mérnöki Kar, \\ egyetemi tanár, Magyarország 1081 Budapest, Népszínház u. 8.; +36 309194929 \\ pokoradi.laszlo@bgk.uni-obuda.hu
}

\begin{abstract}
During technical education it is a very difficult and essential task to develop good logical engineering thinking of students or pupils. One main part of this thinking is to determine the optimal set of required input parameters of the calculation task mentioned above. The LogTreeMM (Logical Tree of Mathematical Modelling) method can help to solve this task. The aim of this paper is to show a this method to determine required parameters of a mathematical model or a simple calculation of physics.
\end{abstract}

Keywords: mathematical model, logical tree, STEM education.

\section{Összefoglalás}

A mérnöki tantárgyak oktatása, tanulás közben fontos feladat, az adott tananyag elsajátításán túl, a hallgatók logikus műszaki problémamegoldó gondolkozásának kialakítása. Ezt segítheti elő jelen tanulmány szerzőinek egyike által nemzetközi folyóiratban publikált LogTreeMM - Logical Tree of Mathematical Modelling (a matematikai modellezés logikai fája) feladatelemző módszer. A cikk ezen eljárást szemlélteti egy egyszerü fizikai példán keresztül.

Kulcsszavak: matematikai modell, logikai fa, STEM képzés.

\section{Bevezetés}

A természettudományi és müszaki jellegü tantárgyak oktatásának egyik legfontosabb feladata - az adott tantárgy tananyagának elsajátítatásán túl - a hallgatók, azaz a leendő mérnökök logikus müszaki problémamegoldó gondolkozásának kialakítása, erősítése. Egyre jelentősebb mértékben terjed az angol nyelvü müszaki, tantárgy-pedagógiai szakirodalomban az úgy nevezett STEM (Science, Technology, Engineering and Mathematics) education kifejezés. A STEM oktatás a tanítás-tanulás rendszerének olyan megközelítése, amely integrálja a természettudomány, a technológia, a mérnöki ismeretek, és a matematika tartalmát, valamint a hozzájuk kapcsolódó készségek fejlesztését segíti elő [1].

Ezen készségek és képességek kifejlesztését képes elősegíteni jelen tanulmány szerzőinek egyike által nemzetközi folyóiratban már publikált LogTreeMM Logical Tree of Mathematical Modelling (a matematikai modellezés logikai fája) modellezési feladatelemző módszer [3]. A módszer lényegében a müszaki megbízhatóság, kockázatkezelés, illetve minőségbiztosítás területein közismerten alkalmazott hibafa elemzés adaptációja. A csúcsese- 
ménnyel analóg a meghatározandó (matematikai szempontból függő) változó. Míg a közvetlenül ismert vagy meghatározható (matematikailag független) úgynevezett alapváltózók, alapmennyiségek a hibafa alapeseményeivel egyeznek meg.

A cikk ezen eljárást szemlélteti egy egyszerü egyetemi fizikai példán keresztül.

\section{Esettanulmány}

A LogTREEMM közérthető szemléltetéséhez egy egyszerü mozgástani példát alkalmazunk. Választásunk azért esett erre, mert a számítási menet megértése nem kíván mélyebb ismereteket semmilyen speciális müszaki vagy természettudományos területen, ám mégis bemutatható a logikai fa minden eleme. Elvünk induktív, tehát a módszer a kézzel fogható példán keresztül hivatott értelmet nyerni.

Gelencsér tankönyvéböl [2] választott példa szerint adott egy $m$ tömegü pont, melyet egy lejtő felső pontjáról $v_{0}$ kezdősebességgel elindítunk. Meghatározandó a tömegpont $E_{m}$ mozgási energiája a lejtő alján.

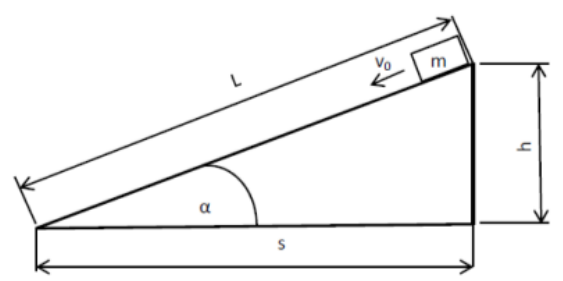

1. ábra. A megoldandó példa szemléltetése

Első lépésként vegyük számba, milyen fizikai összefüggéseket lehet alkalmaznunk a mozgási energiamennyiség meghatározásához, és ezeket hogyan tudjuk matematikai formába önteni.

Az $E_{m}$ kiszámítását két módon végezhetjük el:

$$
E_{m}=\frac{1}{2} m v_{0}^{2}+m g L \sin \alpha
$$

\section{VAGY}

$$
E_{m}=\frac{1}{2} m v_{0}^{2}+m g h
$$

annak függvényében, hogy mely adatokat ismerjük vagy ismerhetjük meg, illetve a lejtő sajátosságai alapján. Ezt a logikai $\boldsymbol{V A G} \boldsymbol{Y}$ kapcsolatot, melyet /1/-el jelölünk, a 2. ábra szemlélteti.

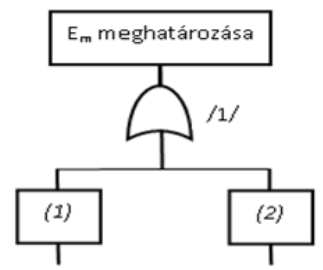

2. ábra. Az /1/logikai kapcsolat szemléltetése

Az (1) összefüggés ágán tovább haladva kell meghatároznunk a megoldáshoz szükséges paramétereket. Azaz ismernünk kell az $m$ tömeget $\boldsymbol{E} \boldsymbol{S}$ az $L$ úthosszt $\boldsymbol{E} \boldsymbol{S} v_{0}$ kezdő sebességet $\boldsymbol{E} \boldsymbol{S}$ a $g$ nehézségi gyorsulást $\boldsymbol{E} \boldsymbol{S}$ az $\alpha$ lejtésszöget. Az első négy közvetlen módon meghatározható (mérhető vagy empirikusan elfogadott értékü), így ezek úgynevezett alapváltozók lesznek.

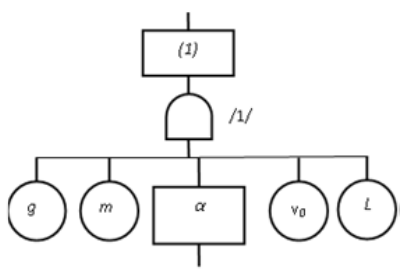

3. ábra. A /2/ logikai kapcsolat szemléltetése

Lehetséges, hogy a lejtő hajlásszöge nem alapváltozó, hanem más adatokból, úgynevezett közbülső váltózókból, származtatható valamely szögfüggvény segítségével. Az $\alpha$ lejtésszög tehát $\boldsymbol{V A G Y}$ elöre meghatározott, alapváltozó, $V \boldsymbol{A G Y}$ a $h$ indulási magasság és $L$ úthossz, $\boldsymbol{V A} \boldsymbol{G} \boldsymbol{Y}$ az $L$ úthossz és $s$ vízszintes vetülete, $\boldsymbol{V} \boldsymbol{A} \boldsymbol{G} \boldsymbol{Y}$ a $h$ indulási magasság és az úthossz $S$ vízszintes vetülete függvényében határozható meg. 
Ezt szemlélteti a /3/ logikai kapcsolat.

$$
\begin{gathered}
\alpha=\arcsin \frac{h}{L} \\
\alpha=\arccos \frac{s}{L} \\
\alpha=\operatorname{arctg} \frac{h}{S}
\end{gathered}
$$

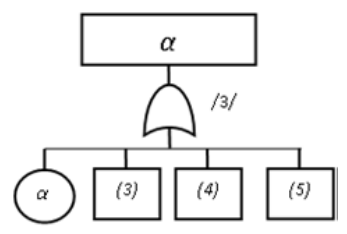

4. ábra. A /3/ logikai kapcsolat szemléltetése

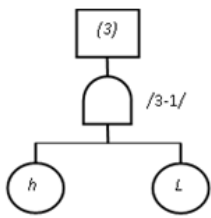

5. ábra. A /3-1/ logikai kapcsolat szemléltetése

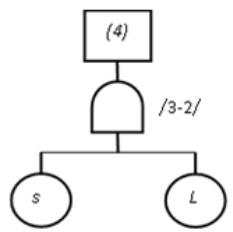

6. ábra. A /3-2/ logikai kapcsolat szemléltetése

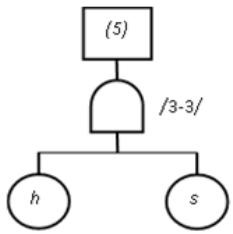

7. ábra. A /3-3/logikai kapcsolat szemléltetése

Így az (1) minden ágában eljutottunk az alapváltozókig. Azonban ezt az összefüggést csak abban az esetben használhatjuk, ha a pálya lejtésszöge állandó. Ezért - adott esetekben - a feladat csak a (2) összefüggés alapján oldható meg.

A (2) összefüggés kiszámításához szükséges négy paraméter ismerete, ami a /4/ jelü $\boldsymbol{E} \boldsymbol{S}$ logikai kapcsolatot jelenti. Azaz ismernünk kell az $m$ tömeget $\boldsymbol{E} \boldsymbol{S} v_{0}$ kezdösebességet $\boldsymbol{E} \boldsymbol{S}$ az indulási pont $h$ magasságát $\boldsymbol{E} \boldsymbol{S}$ a $g$ nehézségi gyorsulást. Ezek közül mindegyik alapváltozó, tehát a (2) összefüggés minden szükséges paraméterét meghatároztuk.

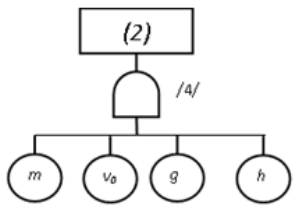

8. ábra. A /4/ logikai kapcsolat szemléltetése

A feladat teljes logikai fája a 9. ábrán látható.

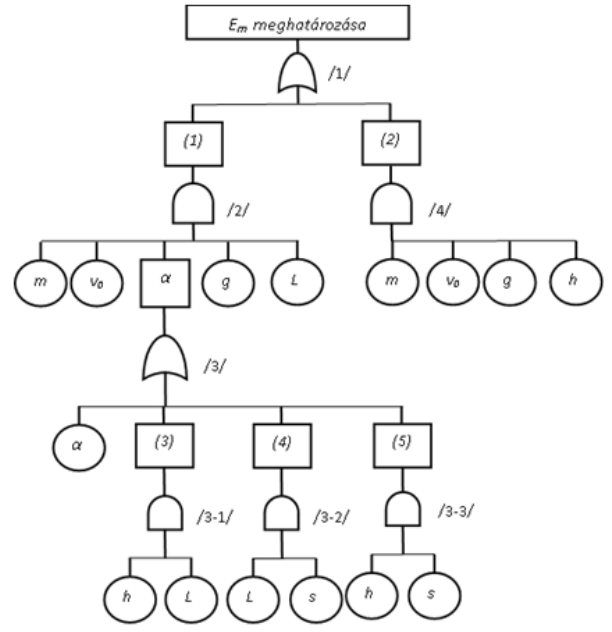

9. ábra. A teljes logikai fa

Miután meghatároztuk a mérhető és nem mérhető, de a feladat megoldásához szükséges paramétereket, összefoglalhatjuk őket halmazműveletek segítségével. Ehhez elsőként mindegyik logikai kapcsolathoz tartozó alapváltozók halmazait kell meghatároznunk.

$$
x_{1}=\varnothing
$$




$$
\begin{gathered}
x_{2}=\left[v_{0} ; \quad g ; \quad L ; \quad m\right] \\
x_{3-0}=[\alpha] \\
x_{3-1}=\left[\begin{array}{ll}
h ; & L
\end{array}\right] \\
x_{3-2}=\left[\begin{array}{ll}
s ; & L
\end{array}\right] \\
x_{3-3}=\left[\begin{array}{ll}
h ; & s
\end{array}\right] \\
x_{4}=\left[\begin{array}{lll}
m ; & v_{0} ; & g ;
\end{array}\right]
\end{gathered}
$$

A feladat lehetséges megoldásaihoz szükséges alapadatok meghatározásához a teljes logikai fa láncolataiban szereplő logikai kapcsolatok alapváltozói halmazának unióját kell képeznünk. Azaz esetünkben:

$$
\begin{aligned}
& x_{A}=x_{1} \cup x_{2} \cup x_{3-0}=\left[v_{0} ; \quad g ; \quad L ; \quad m ; \alpha\right] \\
& x_{B}=x_{1} \cup x_{2} \cup x_{3-1}=\left[v_{0} ; \quad g ; \quad L ; \quad m ; h\right] \\
& x_{C}=x_{1} \cup x_{2} \cup x_{3-2}=\left[v_{0} ; \quad g ; \quad L ; \quad m ; s\right] \\
& x_{D}=x_{1} \cup x_{2} \cup x_{3-3}= \\
& =\left[v_{0} ; \quad g ; \quad L ; \quad m ; h ; s\right] \\
& x_{E}=x_{1} \cup x_{4}=\left[m ; \quad v_{0} ; g ; h\right]
\end{aligned}
$$

A fentiekben meghatározott alapváltozó halmazok ismeretében az alábbi következtetéseket tudjuk levonni az adott fizikai példa megoldásával kapcsolatban:

a) a kitüzött feladat, a test mozgásmennyiségének meghatározására öt megoldás lehetséges, melyekhez a szükséges adatokat az $x_{A} ; x_{B} ; x_{C} ; x_{D}$ és $x_{E}$ halmazok adják meg;

b) a megoldáshoz szükséges legtöbb adatot az $x_{D}$ halmaz tartalmazza, amely az (1) és (5) egyenletek alkalmazását jelenti;

c) a megoldáshoz szükséges legkevesebb adatot az $x_{E}$ halmaz tartalmazza;

d) a ,legrövidebb" megoldást a logikai fa (2) egyenlethez tartozó ága mutatja, mely egyben megegyezik a legkevesebb szükséges adathoz tartozó megoldással;

e) a „leghosszabb" megoldást a logikai fa (1)-(3); (1)-(4) és (1)-(5) egyenletek által megadott ágai adják meg.

Meghatározhatjuk még a fenti halmazok $x_{\text {min }}$ metszete is, mely azon jellemzők halmazát adja meg, melyek ismerete feltétlen szükséges a feladat megoldásához.

$$
\begin{aligned}
& x_{M I N}=x_{A} \cap x_{B} \cap x_{C} \cap x_{D} \cap x_{E}= \\
& =\left[v_{0} ; g ; m\right]
\end{aligned}
$$

\section{3. Összegzés}

Tanulmányunk egy egyszerü esetpéldán keresztül szemlélteti a matematikai modellezés, a modell felállításához szüksélges jellemzők meghatározásának logikai fát alkalmazó módszerét.

A Szerzők további célja több, hasonló mintapélda kidolgozása, valamint ezen példák alkalmazásának bevezetését a müszaki felsőoktatásban. Például az Óbudai Egyetem Bánki Karán folyó különböző szintü és nevü rendszertechnika kurzusok oktatása során.

\section{Tisztelt Olvasó!}

Ha a tanulmány olvasása közben az adott példára más megoldást is kigondolt, akkor a munkánk már elérte célját.

Köszönjük!

A Szerzők

\section{Szakirodalmi hivatkozások}

[1] Bybee, Rodger W.: What IS STEM Education?, Science, Vol. 329. 2010. 996. oldal

[2] Gelencsér Endre: Mozgástan zárthelyi feladatok BSc, Szent István Egyetemi Kiadó, Gödöllő:2014. 124 oldal

[3] Pokorádi László: Logical Tree of Mathematical Modeling, Theory \& Application of Mathematics \& Computer Science 2015/1. 20-28 oldal. 